\title{
Badania, dydaktyka, rynek pracy - koncepcja studiów dwuprzedmiotowych
}

\section{Research, didactics, job market - concept of two-subject studies}

\author{
Krzysztof Skibski
Uniwersytet im. Adama Mickiewicza w Poznaniu
}

\begin{abstract}
The lecture concerns the concept of teaching the Polish language and culture, taking into account traditional research context in contemporary scientific practice as well as current situation on the job market. It combines two humanities in one program and involves the participation of two educational units in the teaching process (one of which being the administrator of the faculty). An important effect of such a method is mastering two subjects as the competence value of the graduate as well as good knowledge of two methodology traditions and disciplines, which influence each other. The exposure of two contexts selected that way contributes to raising the attractiveness of studies, allowing the graduate - especially a teacher - to adapt to the changing conditions of work better.

The Poznan Institute of Polish Philology has launched four such faculties recently (combined with History, Ethics, Classical philology and German philology) and the experience gained not only while working on the programs but also while teaching the first year students, allowed for these analyses and conclusions (as well as questions).
\end{abstract}

Key words: humanities; two-subject studies; dual studies; BA; general academic mode.

Streszczenie: Artykuł dotyczy koncepcji kształcenia polonistycznego uwzględniającego zarówno tradycyjne konteksty badawcze we współczesnej filologicznej praktyce naukowej, jak i sytuację na współczesnym rynku pracy. Polega ona na łączeniu dwu dyscyplin humanistycznych w jednym programie kształcenia i realizowaniu procesu dydaktycznego przez dwie jednostki naukowo-dydaktyczne (jedna z nich jest administratorem kierunku). Ważnym efektem takiej metody jest dwuprzedmiotowość jako walor kompetencyjny absolwenta, a także dobra orientacja w dwu tradycjach metodologicznych i swoistości dyscyplin wzajemnie na siebie oddziałujących. Eksponowanie dobranych w ten sposób kontekstów przyczynia się niewątpliwie do uatrakcyjnienia studiów, jak również powoduje, że absolwent - zwłaszcza nauczyciel - lepiej adaptuje się do zmiennych warunków pracy.

Poznańska polonistyka uruchomiła w ostatnim czasie cztery takie kierunki (w połączeniu z historią, etyką, filologią klasyczną i filologią germańską), a doświadczenia zebrane podczas pracy nad programami, jak również podczas pracy z pierwszymi rocznikami studentów, dały podstawy do niniejszych analiz i wniosków (a także pytań). 
Słowa kluczowe: humanistyka, studia dwuprzedmiotowe, studia dualne, profil ogólnoakademicki.

\section{Humanistyczna dyspersja}

Studia w systemie bolońskim to hasło, które niezmiennie prowokuje do dyskusji. Jest tak mimo czasu, który upłynął od upowszechnienia tej formuły, choć obecne pokolenie studiujących nie bardzo wyobraża sobie inny model. Gradacja kompetencji, mobilność, możliwość przekwalifikowania lub specjalizacji - to tylko niektóre argumenty, które stały się ważne wśród zwolenników studiowania dwustopniowego (ten schemat jest najczęstszy), ale też służą sceptykom eksponującym powierzchowność krótkich kursów, nieoswojenie ze specyfiką roli społecznej (w przypadku studiów humanistycznych zwłaszcza), a także - tu już dość prosto - brak czasu na solidny marsz przez dyscyplinę.

Zjawiskiem równie często komentowanym jest modułowość programów studiów. Wartość jednostkowego wyboru jest tu niekwestionowanym atutem, wzmacnia to bowiem indywidualizm studiującego, pozwala na łatwiejszą i efektywniejszą adaptację, a także zapewnia możliwość rozumnego budowania wspomnianego przyrostu kompetencji. Można więc wybierać np. dodatkowe przedmioty będące efektem indywidualnych projektów badawczych kadry naukowo-dydaktycznej, można słuchać wykładów prezentujących podstawy dziedziny, jej historię, ale też temperament naukowca, jego sposób interpretacji znanych faktów czy wreszcie - odwagę wizjonera. Wybierać można też specjalizacje zawodowe lub badawcze, a także całe bloki zajęć tematycznych. Oczywiście moduły to także lektoraty języków obcych oraz seminaria dyplomowe. Tak sytuacja wyboru przedstawia się w wielu krajach europejskich.

Naturalnie podstawowy w tym wszystkim jest wybór nadrzędny - studia jako takie, a potem ich kategoria. Tu już zaczynają się sprawy silniej związane ze standardem pojmowania roli studiów wyższych, kierunki humanistyczne, ścisłe, ekonomiczne, techniczne to bowiem silne kategorie projektów społecznych (często charakteryzowanych w znacznym uproszczeniu), mniej zaś - wykładniki predyspozycji i predylekcji adeptów.

Kierunki humanistyczne muszą od jakiegoś czasu w Polsce mocować się z opinią, która motywowana jest raczej potoczną interpretacją powinności i celów społecznych aniżeli programem studiów, adekwatnością do dynamiki świata współczesnego czy wreszcie - stopniem trudności studiowania. Przyjmuje się bardzo często w refleksji potocznej (tak też wciąż często myślą kandydaci na studia), że humanistyka jest łatwa, raczej spekulatywna i mało praktyczna. Dalszy ciąg myślenia jest więc relatywny - łatwo się studiuje i nie potrzeba szczególnych talentów ani umiejętności, ale też brak perspektyw na pracę z powodu dużej liczby niewyspecjalizowanych absolwentów. 
Do tego należy dodać wciąż silne społeczne przekonanie, że studia należy skończyć, ponieważ jest to zwiększenie szans na rynku pracy. Myśl jest naturalnie słuszna pod warunkiem, że studia wyższe nie są traktowane zerojedynkowo - są lub ich nie ma. Karkołomne bowiem jest udowadnianie, że sam fakt ukończenia obojętnie jak wybranych i prowadzonych studiów zasadniczo zwiększa szanse na zdobycie bardzo dobrej pracy.

Taki - w dużym skrócie - może być kontekst dalszych rozważań. Wszystkie przedstawione obserwacje, zaprezentowane rozwiązania i efekty odnoszą się do polskich doświadczeń - głównie związanych z poznańską polonistyką. Ponieważ jednak mowa tu także o współpracy z innymi wydziałami (często też - innymi ośrodkami), to można te uwagi traktować jako drobny głos w dyskusji na temat współczesnego studiowania w odniesieniu do konkretnych uwarunkowań społeczno-historyczno-gospodarczych. Humanistyczna dyspersja wyzyskiwałaby wówczas dwa znaczenia - rozproszenie oraz przemieszczenie, bycie $\mathrm{w}$ innym miejscu. Oba rozumienia tej metafory byłyby obrazowaniem dającym się odnieść do opisanej wcześniej sytuacji.

\section{Studia dualne a studia dwuprzedmiotowe - akademickość}

Jednym z pomysłów na uporządkowanie procesu kształcenia w szkołach wyższych było w ostatnich latach w Polsce rozdzielenie profili kierunków (pierwszego i drugiego stopnia) na ogólnoakademicki i praktyczny ${ }^{1}$. Podział ten był konsekwencją przemian, które w szkolnictwie miały miejsce wcześniej. Ogólnoakademickość pojmowano bowiem jako silny związek z badaniami prowadzonymi przez jednostkę. Udział w pracach badawczych ma zapewnić studentom lepszą orientację we współczesnych nurtach naukowych, wprowadzić w specyfikę pracy, a także (co bardzo ważne) ukazać zależności i związki charakteryzujące świat nauki i codzienną aktywność człowieka. Ten profil - mimo braku jednoznacznej wykładni - odpowiadał bardziej studiom proponowanym w uznanych ośrodkach akademickich, reprezentatywnych ze względu na dokonania pracujących tam specjalistów, ze względu na szkoły badawcze i wybitne publikacje, które dokumentują aktywność akademickiego środowiska. Profil praktyczny natomiast był z początku utożsamiany ze studiami pierwszego stopnia (licencjackimi), co pokrywało się z myśleniem o takich studiach jako o możliwości zdobycia wiedzy, kompetencji i umiejętności niezbędnych do rozpoczęcia pracy zawodowej. W nowszych opracowaniach widać jednak wyraźnie, że profil praktyczny lepiej pasuje do studiów prowadzonych przez jednostki mniej zaawansowane naukowo, o mniejszych lub żadnych dokonaniach badawczych, tu także - wyższych szkół zawodowych. Nie oznacza to wcale, że kierunki ogólnoakademickie są niepraktyczne, choć zapewne nieobeznany

\footnotetext{
1 Zob. Rozporządzenie Ministra Nauki i Szkolnictwa Wyższego z 26 września 2016 r. w sprawie warunków prowadzenia studiów - obowiązujący akt prawny: http://isap.sejm.gov.pl/Deta$\underline{\text { ilsServlet? } i d=W D U 20160001596}$ (dostęp 5.10.2016 r.).
} 
odbiorca mógłby tę niekategorialność nazw w taki właśnie sposób zracjonalizować. Różnica tkwi najpierw w kadrze, potem w sposobie funkcjonowania szkoły wyższej, a następnie - w formie zajęć i specyfice oczekiwanych efektów. Absolwent kierunku praktycznego ma mieć za sobą godziny pracy w branży, którą wybrał, ma znać konkretne sposoby wdrażania uznanych rozwiązań do codziennej aktywności, a także - ma dysponować wykształceniem celowym, będącym $\mathrm{w}$ miarę precyzyjną projekcją jego dalszej kariery zawodowej.

Absolwent studiów ogólnoakademickich musi być w tym miejscu scharakteryzowany swoiście. Studia o takim profilu są determinowane przez aktywność badawczą jednostki, ale nie oznacza to wcale, że studia takie nie dają solidnych podstaw do kariery zawodowej². Nie jest więc tak, że studenci tego typu kierunków nie mają kontaktu z praktyką - mają czasem znacznie większą. Wynika to choćby z tego, że metody projektowe wykorzystywane w kształceniu ogólnoakademickim mogą stawiać inne cele przed uczestnikami zajęć. Rozwiązywanie typowych i nietypowych problemów na podstawie poznanych zmiennych, kwerendy poprzedzające opracowanie czy wdrożenie modelu, a także - zaawansowane procesy społeczne, które wpływają na pracę o stopniowalnej zadaniowości w grupach, to tylko niektóre konkretne argumenty na rzecz inaczej pojmowanej praktyczności. Oczywiste też jest ponadto, że jeśli dany ośrodek naukowy szczyci się swoimi szkołami badawczymi, wybitnymi specjalistami w różnych dziedzinach, rozległą współpracą instytucjonalną, to praktyczność tego typu studiów akademickich jest niekwestionowana. Być może więc tylko nomenklatura mąci w tym przypadku percepcję podobnie jak w przypadku studiów humanistycznych.

$\mathrm{Na}$ tym tle pojawia się w polskiej rzeczywistości inna para pojęć - studia dualne oraz (najważniejsze $\mathrm{w}$ tym opracowaniu) studia dwuprzedmiotowe. Dwoistość jest więc tu cichym bohaterem, choć jego rola - co chyba nie powinno dziwić - okazuje się w istocie ambiwalentna.

Podstawę studiów dualnych stanowi współpraca jednostki naukowo-dydaktycznej z pracodawcą. Nie jest to jednak działanie okazjonalne czy dodatkowe - w tym przypadku chodzi o współprowadzenie studiów, a więc współtworzenie programu i realne zróżnicowanie form aktywności studenta. Absolwent takiego kierunku to najczęściej pracownik instytucji czy firmy współprowadzącej kierunek studiów. W trakcie procesu dydaktycznego student poznaje konkretne stanowiska pracy, a jednocześnie rozbudowuje swoje kompetencje zawodowe w ścisłym związku z zapleczem intelektualnym uczelni oraz pracodawcy ${ }^{3}$. Studia dualne są więc determinowane

\footnotetext{
${ }^{2}$ Warto w tym miejscu zwrócić uwage na książkę dokumentującą konferencję naukową, która odbyła się w poznańskim Instytucie Filologii Polskiej w 2015 roku - Polonista na rynku pracy. O strategiach dostosowania kształcenia studentów do wyzwań rynku pracy, 2016, Gis A., Wobalis M. (red.), Poznań.

${ }^{3}$ W Poznaniu doskonale funkcjonuje współpraca Politechniki Poznańskiej z Volkswagen Poznań, Solaris Bus \& Coach S.A. czy Beiersdorf Manufacturing Poznań sp. z o.o.
} 
przez lokalne uwarunkowania, co zwiększa swoistość projektów dydaktycznych w zakresie szkolnictwa wyższego.

Studia dwuprzedmiotowe natomiast stanowią innego typu reakcję na współczesną sytuację w szkolnictwie wyższym, a także - na rynku pracy. Należy podkreślić, że omawiana koncepcja studiów dwuprzedmiotowych odnosi się wyłącznie do pierwszego stopnia (studiów licencjackich), co ma istotny związek z projektem dalszych ścieżek absolwenta.

Podstawowe założenia są następujące. Studia dwuprzedmiotowe, a więc łączące w programie dwie dyscypliny naukowe, dwie specjalizacje lub dwa przedmioty (w odniesieniu do terminologii stosowanej w oświacie), przeznaczone są dla osób, które chcą zostać nauczycielami lub chcą kontynuować studia na podstawie rozbudowanych efektów kształcenia. Program studiów jest każdorazowo opracowywany przez dwie jednostki podstawowe (np. dwa wydziały uniwersyteckie), a zajęcia prowadzone przez specjalistów z obu tych jednostek. W przypadku przyszłych nauczycieli mamy więc do czynienia ze studentami, którzy realizują swoisty program opracowany nie jako proste połączenie dwóch odrębnych kierunków (można bowiem przecież studiować dwa kierunki jednocześnie), ale jako wzajemnie się dookreślająca dyskursywna struktura. W ten sposób nie mamy do czynienia z przyrostem kompetencji tożsamym z efektami studiów na dwu kierunkach - jest to konsekwencja relacji determinowanej nierzadko przez wspólne inicjatywy badawcze, wspólne konferencje czy projekty edukacyjne (we współpracy np. z ośrodkami kultury czy szkołami).

Idea dwuprzedmiotowości jest oczywiście - w polskiej tradycji kształcenia - problematyczna. Analiza efektów kształcenia obserwowanych u absolwentów, jak również ograniczenia wprowadzone przez Standardy kształcenia przygotowujacego do wykonywania zawodu nauczyciela w 2012 roku$^{4}$, spowodowały nierzadko krytyczną ocenę rezultatów tak pomyślanego procesu kształcenia. Warto dodać, że również wytyczne dotyczące konstruowania programów kształcenia nie wychodzą tej podwójności naprzeciw. Pogodzenie reguł odnoszących się do liczby godzin określonych przedmiotów, dystrybucji punktów ECTS, wymiaru praktyk zawodowych, a także wymaganego stopnia fakultatywności w obrębie programów kształcenia, mogło powodować konsekwencje w postaci niespójnych programów lub nieproporcjonalnych czy niekompletnych modułów przedmiotowych. Weryfikatorem takiej sytuacji okazywał się po części rynek pracy, obnażając zbyt powierzchowne przygotowanie absolwentów do podjęcia pracy nauczyciela dwóch przedmiotów.

Wszystkie te wątki pojawiały się również w poznańskich dyskusjach na temat dwuprzedmiotowości. Ograniczenia formalne przy budowaniu programów kształcenia istotnie utrudniały realizację niektórych koncepcji

${ }^{4}$ Rozporządzenie Ministra Nauki i Szkolnictwa Wyższego z 17 stycznia 2012 r. w sprawie standardów kształcenia przygotowującego do wykonywania zawodu nauczyciela, zob. http://isap.sejm. gov.pl/DetailsServlet?id=WDU20120000131 (dostęp 5.10.2016 r.). 
szczegółowych - zwłaszcza w odniesieniu do studiów drugiego stopnia. Dla twórców programów stało się bowiem jasne, że przy obecnym stanie prawnym studia magisterskie muszą dotyczyć pojedynczych uprawnień, a więc absolwent studiów licencjackich stanie przed koniecznością wyboru dalszego ciągu w zależności od sprofilowanych zainteresowań przedmiotowych. Stan taki jednak - w opinii twórców omawianych tu pokrótce programów - nie podaje w wątpliwość idei studiów dwuprzedmiotowych. Po pierwsze dlatego, że studia licencjackie są w istocie propedeutyczne (także w odniesieniu do warsztatu nauczyciela czy instruktora w ośrodku kultury) i stanowią w tym sensie solidną podstawę domagającą się jednak - choćby z uwagi na praktykę - dalszego kształcenia. Po drugie - absolwent może wybrać pomiędzy studiami w zakresie jednego z dwu przedmiotów (osobne kierunki i uprawnienia) lub - ze względu na znacznie mniejszą liczbę godzin w programie studiów magisterskich - kontynuować kształcenie na obu kierunkach studiów ${ }^{5}$. Dotychczasowe doświadczenia poznańskich polonistów pokazują, że wartość studiów dwuprzedmiotowych objawia się tym silniej, im mocniej eksponowany jest profil ogólnoakademicki tego typu studiów. Kształcenie studentów połączone z zaplanowaną i ewaluowaną współpracą ze szkołami (klasy patronackie, zajęcia warsztatowe dla młodzieży, całoroczna praktyka ciągła), a także $\mathrm{z}$ nieustannym dostępem do efektów badań naukowych prowadzonych $\mathrm{w}$ jednostce, gwarantuje stworzenie odpowiednich podstaw warunkujących nie tylko jakość przyszłej pracy zawodowej, lecz również jakość późniejszych decyzji o dalszym kształceniu.

Należy jednak z całą mocą podkreślić, że wszystkie zastrzeżenia, które zrodziły się w ostatnich latach w związku z koncepcją kształcenia dwuprzedmiotowego, są istotne, co tym wyraźniej pokazuje nieustanną potrzebę dyskusji na temat tego modelu.

Poznańska polonistyka - w ścisłej współpracy z jednostkami partnerskimi - prowadzi dziś cztery takie dwuprzedmiotowe kierunki. Na tych przykładach można pokazać potencjał tego typu rozwiązań, choć od razu warto zaznaczyć, że dopiero etap wdrożenia i ewaluacji umożliwia realną pracę nad optymalnymi programami kształcenia.

\section{Kontekstowość a interakcyjność - krótka historia kierunków}

\section{Historia i społeczeństwo}

Pierwszą próbą stworzenia tego typu dwuprzedmiotowego kierunku był projekt studiów polonistyczno-historycznych. Ponieważ partnerzy - Instytut Historii i Instytut Filologii Polskiej - mieli już doświadczenia

\footnotetext{
${ }^{5}$ Kierunki te prowadzone są przez współpracujące jednostki uniwersyteckie, co umożliwia np. prowadzenie skorelowanych projektów magisterskich, uczestnictwo we wspólnie przygotowywanych sympozjach i dyskusjach, a także praktykę w placówkach intensywnie współpracujących z obiema jednostkami.
} 
w prowadzeniu wspólnych studiów ${ }^{6}$, dlatego podjęto decyzję o jednoznacznym nauczycielskim charakterze nowego projektu. W polskim systemie oświaty studia licencjackie dają uprawnienia do nauczania w szkole podstawowej. Po zdobyciu dyplomu można kontynuować kształcenie na którymś z kierunków oferowanych przez współpracujące jednostki (by zdobyć m.in. uprawnienia do nauczania w gimnazjum i szkołach ponadgimnazjalnych) w zakresie filologii lub historii, albo rozpocząć pracę zawodową jako nauczyciel dwu przedmiotów. W odniesieniu do polonistyki i historii są to odpowiednio - język polski oraz historia i społeczeństwo. Program studiów został skonstruowany na podstawie siatki przedmiotów dotychczas wypracowanych w obu jednostkach. Skorelowano przy tym porządek następujących po sobie przedmiotów tak, by kolejne semestry pozwalały na przejście od czasów antycznych (kultury, literatury, historii) po współczesność. Poza dwoma dużymi modułami zajęć polonistyczno-historycznych w programie znalazł się moduł trzeci - zajęcia specjalistyczne związane z przygotowaniem do pracy nauczyciela. Moduł ten został wzbogacony o zajęcia unikatowe, które wyraźnie wskazują na specyfikę pracy z uczniami w wieku 10-13 lat - praca z uczniem o specjalnych potrzebach edukacyjnych, praca z uczniem zdolnym, literatura dla dzieci itp. Korelacja modułów historycznoliterackich i historycznojęzykowych z modułami historycznymi pozwoliła na silniejszą pozycję zajęć bezpośrednio związanych ze współczesnością. Dotyczy to zarówno kompetencji językowych, jak i np. sprawności w zakresie technologii informacyjnych (bazy danych, korpusy, słowniki sieciowe). W programie przewidziano także rozbudowany blok praktyk, które mogą być prowadzone $\mathrm{w}$ systemie ciągłym. Praktyki realizowane są $\mathrm{w}$ porozumieniu z placówkami stale współpracującymi z obiema jednostkami uniwersyteckimi. Ta ostatnia kwestia, a także fakt wspólnego realizowania projektów edukacyjnych czy naukowych, daje podstawy do myślenia o tego typu studiach podobnie jak o studiach dualnych. Ścisła współpraca z przedstawicielami środowisk nauczycielskich (także na etapie opracowywania programu studiów) powoduje, że studenci pracujący w relatywnie małych grupach są bardzo dobrze zaznajomieni ze specyfiką pracy we współczesnej szkole. Dotyczy to także sytuacji zatrudnienia - łatwiej o pracę wówczas, gdy ma się uprawnienia do nauczania dwu przedmiotów. Co ważne uprawnienia zdobyte dzięki metodzie interakcji pomiędzy dyscyplinami, a nie w drodze postępującej kumulacji.

\section{Etyka}

Kolejną próbą stworzenia kierunku dwuprzedmiotowego był projekt studiów polonistyczno-filozoficznych, także nauczycielskich, dzięki którym absolwent zdobywa uprawnienia do nauczania języka polskiego i etyki. Współpraca IFP z Instytutem Filozofii ma także swoje wieloletnie

\footnotetext{
${ }^{6}$ Przez kilka lat prowadzony był tzw. makrokierunek - filologiczno-historyczne studia środkowoeuropejskie, a więc studia będące próbą połączenia dwu kierunków z jednoczesnym wyeksponowaniem specjalnie stworzonych przedmiotów, które dotyczyły Europy Środkowej.
} 
tradycje naukowe, nie miała jednak jeszcze tradycji dydaktycznych (poza stałą obecnością kursu z filozofii w programie studiów polonistycznych na wszystkich stopniach kształcenia). To zatem jeszcze wyraźniejszy przykład współtworzenia studiów o profilu akademickim, których program powstał dzięki intensywnej działalności badawczej, konferencyjnej i publikacyjnej. Nie przypadkiem więc koledzy filozofowie od początku używali wobec tych studiów określenia studia dualne - nie do końca w zgodzie z obowiązującą wykładnią, ale w ścisłym związku ze sposobem myślenia o tego typu pomyśle na kształcenie.

Etyka jest w polskiej szkole (mniej popularną dotychczas) alternatywą dla lekcji religii. Na podstawie analizy programu studiów można tylko ubolewać nad tym, że nie jest to przedmiot obowiązkowy. Z pewnością jednak elitarne dziś grono absolwentów studiów dwuprzedmiotowych będzie z powodzeniem realizować założenia tego przedmiotu, mając przy tym solidne zaplecze polonistyczne, a więc umiejętność odnoszenia omawianej problematyki do różnorodnych tekstów kultury, jak również zdolność do krytycznego czytania literatury przedmiotu.

Projekt studiów polonistyczno-filozoficznych zainspirował twórców do rozważania koncepcji wspólnych studiów magisterskich. Jest to uzasadnione, ponieważ bardzo często studenci polonistyki wybierają filozofię jako drugi kierunek studiów, uczestniczą w pracach kół naukowych (które mają także coraz więcej wspólnych inicjatyw), piszą prace dyplomowe na pograniczu tych dwu dyscyplin.

Już na tych przykładach można zobaczyć, że dwuprzedmiotowość jest konkretną odpowiedzią z jednej strony na praktykę badawczą czy popularyzatorską jednostek uniwersyteckich, z drugiej - na uważnie analizowany rynek pracy. Nie należy przy tym zapominać o roli kształtowania kompetencji przyszłych pokoleń absolwentów. Dwuprzedmiotowość jest więc także wyrazem starań o jakość przyszłej refleksji humanistycznej.

\section{Kultura antyczna}

Na tym tle wyjątkowo kameralną, ale nie mniej ważną propozycją są prowadzone z Instytutem Filologii Klasycznej studia latynistyczno-polonistyczne. W strukturze programu - wraz z modułem polonistycznym - znalazły się zajęcia dotyczące antyku greckiego i rzymskiego, łaciny, mitologii, a także szeroko pojmowanej recepcji motywów antycznych w świecie współczesnym. Studia na tym kierunku nie dają co prawda uprawnień do nauczania dwu przedmiotów (nie ma bowiem łaciny w programie szkoły podstawowej), stanowią jednak - przez rozbudowany kontekst - ważną podstawę studiów magisterskich (język łaciński pojawia się w niektórych szkołach gimnazjalnych i ponadgimnazjalnych), a także wartościowe wzmocnienie polonistycznej części programu. 


\section{Kultura obszaru niemieckojęzycznego}

Najnowszą inicjatywą poznańskiej polonistyki są wspólne studia prowadzone z Instytutem Filologii Germańskiej - polonistyczno-germanistyczne. I tu - podobnie jak w poprzednich przypadkach - wspólne działania naukowe i popularyzatorskie dały podstawę działaniom edukacyjnym. Jednocześnie warto podkreślić, że inicjatywa utworzenia studiów licencjackich motywowana była przede wszystkim doświadczeniami zdobytymi w trakcie prowadzenia unikatowych studiów magisterskich „Polacy i Niemcy w Europie”. Studia licencjackie więc to $\mathrm{z}$ jednej strony możliwość przygotowania się do pracy w zawodzie nauczyciela lub tłumacza, z drugiej zaś - intensywna nauka poprzedzająca bardzo atrakcyjne (choć też wymagające) międzynarodowe studia polsko-niemieckie współprowadzone przez dwa uniwersytety ${ }^{7}$.

\section{Ciągi dalsze?}

Na podstawie przyjętych przesłanek, a także dzięki obserwacji dotychczasowego przebiegu procesu kształcenia na kierunkach dwuprzedmiotowych można rozpatrywać inne połączenia dyscyplin, które mają swoją motywację $\mathrm{w}$ praktyce badawczej i statutowej działalności konkretnych ośrodków akademickich, dzięki temu w jakiejś mierze projektują przyszłe zapotrzebowanie na rynku pracy. Takie programy studiów są więc po części efektem krytycznej analizy sytuacji bieżącej (z wykorzystaniem opinii potencjalnych pracodawców zorientowanych w niuansach aktualnego stanu prawnego), po części zaś - prognozą modelu kompetencji w zależności od działalności naukowej ważnych ośrodków w kraju. Na tym właśnie polega istota akademickości, która - w odniesieniu do studiów pierwszego stopnia - nie jest tożsama z abstrahowaniem od praktyki.

W odniesieniu do studiów nauczycielskich można więc oczywiście zaproponować połączenia z innymi językami Europy (według modelu studiów kulturowych), a także studia łączące polonistykę z lingwistyką komputerową czy socjologią (dotyczy to zwłaszcza nowych mediów). Tu jednak potrzebna jest najpierw intensyfikacja wspólnych badań i dyskusji, dopiero wówczas można będzie efektywnie opracowywać podstawy programu odnoszącego się do miejsc wspólnych, a także formułowanych w konsekwencji pytań.

\section{Humanistyka a rynek pracy - potrzeba rewizji (fluktuacje intelektualne)}

Humanistyka nie jest służebna wobec rynku pracy, a więc nowoczesne kierunki humanistyczne powinny odnosić się do odważnych projektów intelektualnych, do trwających dyskusji, powinny łączyć praktykę z eksploracją, a eksperyment z hipostazą. Dynamika odbioru w procesie czytania tekstów kultury czy doświadczania przemian w językach jest tak duża, że nie sposób poprzestać na wykorzystywaniu modeli sprawdzonych w dotychczasowej

\footnotetext{
${ }^{7}$ Studia magisterskie prowadzone przez Uniwersytet im. Adama Mickiewicza w Poznaniu oraz Uniwersytet Christiana Albrechta w Kilonii.
} 
praktyce zawodowej. Stąd właśnie wynika idea studiów przygotowujących do dalszych wyborów, decyzji czy form aktywności. Studia dwuprzedmiotowe nie są więc prostym rozszerzeniem kontekstów dyscypliny podstawowej, są raczej interakcją dwu dyscyplin, która ukazuje inne możliwości podejmowania działań zarówno na gruncie badań naukowych, jak i w pracy zawodowej. Poznańskie inicjatywy wyrosły z troski o przyszłą rolę twórczego nauczyciela, który będzie lepiej adaptował się do zmieniających się okoliczności, a także umiał problematyzować to wszystko, co będzie stanowić naturalne okoliczności edukacyjne.

\section{Wnioski}

Podsumujmy pokrótce powyższe rozważania:

a. odzwierciedlenie badań

Studia dwuprzedmiotowe stanowią podstawowy efekt badań prowadzonych przez uznane jednostki - konsekwencje wspólnych inicjatyw, projektów badawczych oraz tradycji dają solidną podstawę studiom akademickim. Praktyka niezbędna na studiach pierwszego stopnia jest tu motywowana przez badania i nawet na poziomie nauczania szkolnego pozwala nauczycielowi na lepszą adaptację oraz gwarantuje skuteczniejszy samorozwój. Studia dwuprzedmiotowe to także - w przypadku kontynuowania nauki dobra podstawa do rozwijania się w jednej z dwu dziedzin, jak również - do dalszych interakcji. Akcentowanie związku z aktualnymi badaniami naukowymi zapewnia studentom rozleglejszą perspektywę oraz ciągłą potrzebę krytycznego poszerzania wiedzy.

b. proporcje między fakultatywnością a obligatoryjnością modułów

Wydaje się, że w przypadku studiów dwuprzedmiotowych fakultatywność rozumiana jako wolny wybór modułów przynosi mniejsze korzyści niż w przypadku studiów magisterskich. Można więc na podstawie zdobytych doświadczeń zastanowić się nad gradacją nie tylko kompetencji, ale też w związku z tym - fakultatywności. Widać to wyraźnie w odniesieniu do studiów trzeciego stopnia (doktoranckich), których program jest już bardzo mocno zindywidualizowany.

c. integralność praktyki - projekty międzyinstytucjonalne

Praktyka na studiach licencjackich - co oczywiste - doskonale się sprawdza jako integralny element programu. Warto jednak rozważać (i takie obserwacje można poczynić w odniesieniu do doświadczeń poznańskich) silniejszy związek z instytucjami (szkołami, ośrodkami kultury, jednostkami samorządów lokalnych itp.), dzięki czemu możliwe będzie wspólne realizowanie projektów kulturalnych (najlepiej cyklicznych), projektów edukacyjnych czy opracowywanie innowacji edukacyjnych (klasy patronackie, programy autorskie). Ten aspekt studiów dwuprzedmiotowych 
zbieżny jest ze sposobem myślenia o studiach dualnych, choć partner nie jest w tym przypadku stroną zgłaszającą bezpośrednie zapotrzebowanie na absolwentów kierunku.

d. dyskursywna przestrzeń profilowania

Studia dwuprzedmiotowe są niewątpliwie - także z uwagi na problematyczność tej kategorii - dowodem na inicjatywność środowiska akademickiego. Jest to jeden ze sposobów upowszechniania dyskusji na temat roli humanistyki, a więc też - odczarowywania jej (często zbyt prosto definiowanej) misji społecznej. Dyskursywność tego typu projektów akademickich antycypuje $\mathrm{w}$ jakiejś mierze przyszłe spory o formy i metody kształcenia nie tylko na poziomie studiów wyższych, ale - w konsekwencji - na każdym etapie kształcenia ${ }^{8}$.

Wzmocnieniem powyższych przybliżeń niech będą dwa fakty.

Coraz częściej instytucje zgłaszają się do przedstawicieli Wydziału Filologii Polskiej i Klasycznej z prośbą, by wspólnie realizować projekty kulturalne, edukacyjne czy różnego typu innowacje społeczne.

$\mathrm{Z}$ raportu opracowanego w tym roku przez Pracowników Wydziału Nauk Społecznych UAM wynika, że zjawisko trwałego bezrobocia wśród absolwentów Wydziału Filologii Polskiej i Klasycznej nie istnieje.

\section{O Autorze:}

Krzysztof Skibski - językoznawca, pracuje w Instytucie Filologii Polskiej UAM w Poznaniu; zajmuje się językiem współczesnych tekstów literackich, współczesnym językiem polskim (w ujęciu normatywnym i uzualnym) oraz sztuką słowa mówionego; interesuje się badaniami prowadzonymi na pograniczu językoznawstwa i literaturoznawstwa (nie tylko polonistycznego), nowymi metodami badań językoznawczych, a także innymi językami słowiańskimi.

${ }^{8}$ Dyskusja taka już się w Polsce rozpoczęła w związku z przeprowadzaną w tym roku reformą oświaty. Idące za tym zmiany w standardach kształcenia przyszłych nauczycieli będą niewątpliwie czynnikiem intensyfikującym debatę na temat priorytetów w dydaktyce akademickiej. 
